\title{
Experimental Struvite Urolithiasis in Goats
}

\author{
J.A. Corbera, M. Morales, F. Doreste, C. Gutierrez ${ }^{\mathrm{a}}$
}

\author{
Department of Animal Medicine and Surgery \\ Veterinary Faculty, University of Las Palmas \\ 35416, Arucas, Las Palmas, Canary Islands, Spain
}

(Received February 15, 2007; accepted September 28, 2007)

\begin{abstract}
Corbera, J.A., Morales, M., Doreste, F. and Gutierrez, C. 2007. Experimental struvite urolithiasis in goats. J. Appl. Anim. Res., 32: 191-194.

To study the occurrence of the experimental struvite urolithiasis in goats in a semi-arid region of the Canary Islands, where urolithiasis is relatively common, 18 one-year old Canary female goats were divided into three equal groups: Group A received a concentrate ration of 3 parts corn to 1 part cottonseed meal; Group $B$ received the same diet with wheat straw added ad libitum and Group C received a balanced diet for 10 weeks. Crystaluria was observed in all groups, but was more evident in Group A. Goats belonging to this group showed a progressive calcium / phosphorus disbalance. Epithelial cells and bilirubin crystals were also more evident in the Group A. It is concluded that high grain diet resulted in struvite urolithiasis in goats.
\end{abstract}

Keywords: Urolithiasis, struvite, calculi, goat.

\section{Introduction}

Urolithiasis is an important limiting factor in ruminant production that occurs by the interaction of numerous physiological, nutritional and management-related factors. However, calculus composition appears to be directly related to the dietary intake of individual elements (Radostits et al., 2000). Ruminants consuming rations high in phosphorus, such as grain-based feedlot rations, commonly develop phosphate calculi. In goats, clinical obstructive urolithiasis is most frequently seen in young, castrated males and the calculi are usually comprised of phosphate salts, especially apatite and struvite (magnesium ammonium phosphate)

${ }^{\mathrm{a}}$ For correspondence: Tel.: 0034928451115 ;

Fax: 0034 928451142; E-mail: cgutierrez@dpat.ulpgc.es
(Smith and Sherman, 1994). However, there is only a little information in the available literature on the pathogenesis of struvite urolithiasis in goats. In particular, dairy rations have an excessive phosphate concentration (and low $\mathrm{Ca} / \mathrm{P}$ ratio) compared with nutritional requirements for goats. In one study, 17 of 21 small ruminants with obstructive urolithiasis had been fed a pelleted diet intended for horses or lactating cows (Haven et al., 1993).

The scarce production of roughages (as effective fiber) is the main constraint on ruminant production in the Canaries and diets are commonly based on high levels of grains. Thus, it is common to observe struvite calculi in goats (Gutierrez et al., 2000) and particularly in males causing obstructive urolithiasis, both on the field and in abattoirs. 
The purpose of this experiment was to study the pathogenesis of struvite urolithiasis in goats using rations commonly used by farmers in the islands.

\section{Materials and Methods}

Eighteen one-year old Canary female goats, weighing $28-34 \mathrm{~kg}$, were purchased from a commercial dairy goat farm and were maintained for 2 weeks on a commercial diet for goats. Females instead of male goats were used in order to avoid the risk of obstructive urolithiasis, a condition commonly found in male animals with fatal outcome.

After the two weeks of adaptation, the animals were divided into three equal groups. During the 10 weeks experimental period, group A received a concentrate ration of 3 parts corn to 1 part cottonseed meal, a diet previously described to produce struvite urolithiasis in goats (Unanian et al., 1982). Group B received the same diet but with wheat straw added ad libitum. Group $\mathrm{C}$ received a balanced (commercial) diet based on corn, barley, dehydrated alfalfa and wheat straw. Fresh water was always available.

Urine was collected weekly by urethral catheterization ( $3 \mathrm{~mm}$ of diameter) for microscopic examination. Urine analysis was performed within a few minutes after collection using Combur 10 Test ${ }^{\circ}$ (Roche, Germany) for specific gravity, $\mathrm{pH}$, leucocytes, nitrites, protein, glucose, ketones, urobilinogen, bilirubin and presence of blood. Urine was centrifuged at low revolutions (1,500 rpm), sediment obtained was extended in a smear, stained with methylene blue and observed at low magnification (x100).

Blood samples were collected weekly from jugular vein and sera obtained were stored at $-80 \mathrm{C}$ until their processing for blood urea nitrogen (BUN), creatinine, calcium, phosphorous and magnesium with a photometer Ecom F-6124, Eppendorf, using Sigma reagents®.
Ultrasound examination (Kontron $150 \AA$, Kontron Instruments) was performed monthly to assess possible disturbs in the urinary tract. The bladder wall was measured in each checking and possible changes in the urine fluid were also evaluated.

Data obtained were introduced in the statistical package SPSS 12.0 for Windows. ANOVA and Scheffe tests were applied and statistical significance was considered when $\mathrm{P}<0.05$.

\section{Results and Discussion}

The diet used in this study caused urolithiasis in group A (Fig. 1) probably due to several factors such as lack of forage, an increased ingestion of dietary phosphorus (estimated calcium/phosphorus ratio was 1/ 8 ) and also magnesium $(0.76 \%)$. The increases in dietary phosphorus levels result in increased concentration of phosphate ion in ruminant urine (Van Metre et al., 1996). On the other hand, increase in dietary magnesium over $0.6 \%$ can also promote struvite urolithiasis even when the calcium/ phosphorus ratio is balanced (Van Metre and Divers, 2002). The calcium/phosphorus disbalance would also have produced the progressive abnormal growth and bowing deformity of forelimbs in the goats. The diet was partially balanced with the inclusion of wheat straw (group B), but the calcium/

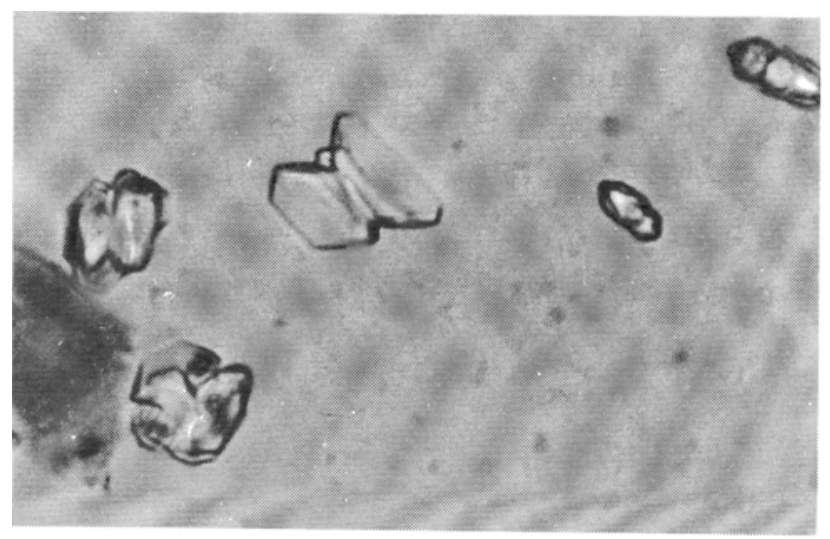

Fig. 1. Struvite crystals and one epithelial cell (left side) in a goat (group A); $x 400$. 
Table 1

Urine analysis results on specific gravity and struvite crystals

\begin{tabular}{cccccccc}
\hline \multirow{2}{*}{ Week } & \multicolumn{3}{c}{ Specific gravity } & & \multicolumn{3}{c}{ Presence of crystals (struvite) } \\
\cline { 2 - 4 } & Group A & Group B & Group C & & Group A & Group B & Group C \\
\hline 1 & $1012 \pm 8$ & $1009 \pm 11$ & $1010 \pm 3$ & & $5(++)$ & $5(+)$ & $2(+)$ \\
3 & $1017 \pm 10$ & $1011 \pm 7$ & $1011 \pm 4$ & & $6(++)$ & $6(+)$ & $1(+)$ \\
4 & $1012 \pm 9$ & $1017 \pm 10$ & $1005 \pm 6$ & $6(+++)$ & $5(++)$ & 0 \\
5 & $1010 \pm 6$ & $1009 \pm 6$ & $1007 \pm 5$ & & $6(++)$ & $5(++)$ & $2(+)$ \\
6 & $1013 \pm 12$ & $1015 \pm 10$ & $1012 \pm 4$ & & $5(+++)$ & $2(+)$ & $1(+)$ \\
7 & $1015 \pm 8$ & $1017 \pm 9$ & $1009 \pm 7$ & & $6(+++)$ & $5(++)$ & 0 \\
8 & $1023 \pm 7^{*}$ & $1023 \pm 9^{*}$ & $1009 \pm 5$ & & $6(++)$ & $6(+)$ & $2(+)$ \\
9 & $1016 \pm 10$ & $1017 \pm 12$ & $1005 \pm 7$ & & $6(++)$ & $3(+)$ & 0 \\
10 & $1018 \pm 9$ & $1015 \pm 12$ & $1011 \pm 8$ & & $5(++)$ & $4(+)$ & $1(+)$ \\
\hline
\end{tabular}

Specific gravity: Mean and standard deviation. *Statistical differences $(\mathbf{P}<0.05)$. +: Mild urolithiasis; ++: Medium urolithiasis; +++: Severe urolithiasis.

phosphorus ratio was still imbalanced (estimated as 1/4). Calcium/phosphorus ratio in group $\mathrm{C}$ was estimated to be $2 / 1$, with no clinical signs of mineral disbalance.

Urine examination showed statistical differences in specific gravity between groups A and B compared with the control group in the $7^{\text {th }}$ week and group $A$ in the $10^{\text {th }}$ week (Table 1). Specific gravity would depend principally on ingestion of water as normal mechanism of homeostasis (Finco, 1997), goats particularly from group A would have ingested a relatively lower volume of water compared with the control group. This fact could also promote the precipitation of minerals in the urinary environment. The presence of crystals in urine was lesser from $5^{\text {th }}$ and $6^{\text {th }}$ weeks in groups $A$ and $B$. Crystaluria can vary in an individual due to many physiological and nutritional reasons; in our study, crystaluria was very evident from the first week of the experiment, particularly in the group A. Probably, the adaptation mechanisms or higher water ingestion could play an important role in this process. Regarding proteinuria and bilirubinuria, the levels found in this study could be considered as normal in concentrate urine (Finco, 1997).

Blood examination revealed no statistical differences between different groups. BUN and serum creatinine are commonly used to evaluate the renal function, which was within normal limits in all animals. On the other hand, great variations on serum calcium, phosphorus and magnesium were not observed despite the disbalanced diet administered to groups A and B. Homeostatic mechanisms of calcium, phosphorus and magnesium would have played an important role in the metabolism of these minerals during the study (Rosol and Capen, 1997).

Ultrasound examination showed no relevant findings. Ultrasonography has been recommended as the most rapid, non-invasive and safest means for calculi diagnosis (Smith and Sherman, 1994), however, the small size of the crystals observed in the urine was not evident by ultrasound. 
In conclusion, young female goats experimentally managed with rations high in grains developed struvite crystaluria and mild increases in urine specific gravity compared to the control group.

\section{Acknowledgements}

This study was supported by the Canary Government, Education Council, Research Project PI 2000/060.

\section{References}

Finco, D.R. 1997. Kidney function. In: Kaneko, J.J., Harvey, J.W. and Bruss M.L (Eds.), Clinical Biochemistry of Domestic Animals. $5^{\text {th }}$ ed. Academic Press, San Diego, CA, pp 441-484.

Gutierrez, C., Escolar, E., Juste, M.C., Palacios, M.P. and Corbera, J.A. 2000. Severe urolithiasis due to trimagnesium orthophosphate calculi in a goat. Vet. Rec., 146: 534.

Haven, M.L., Bowman, K.F., Engelbert, T.A. and Blikslager, A.T. 1993. Surgical management of urolithiasis in small ruminants. Cornell Vet., 83: 47-55.

Radostits, O.M, Gay, C. C., Blood, D. C. and Hinchcliff, K. W. 2000. Veterinary Medicine, $9^{\text {th }}$ ed., W.B. Saunders, pp 479-500.

Rosol, T.J. and Capen, C. 1997. Calcium-regulating hormones and diseases of abnormal mineral (Calcium, phosphorus, magnesium) metabolism. In: Kaneko, J.J., Harvey, J.W. and Bruss M.L (Eds.), Clinical Biochemistry of Domestic Animals. $5^{\text {th }}$ ed. Academic Press, San Diego, CA, pp 619-702.
Smith, M.C. and Sherman, D.M. 1994. Goat Medicine. Lea \& Febiger, Philadelphia. pp 387-409.

Unanian, M.D.S., Silva, A.E.D. and Santa Rosa, J. 1982. Proceedings, Third International Conference on Goat Production and Diseases, Scottsdale, Aristone, Dairy Goat Publication Company, 1982, p. 348. In: Smith, M.C. and Sherman, D.M. (Eds.), Goat Medicine Lea and Fibeger, Philadelphia.

Van Metre, D.C., Fecteau, G., House J.K., George, L.G., Angelos, S.M., Smith, B.P., Thurmond, M.C. and Angelos, J.A. 1996. Obstructive urolithiasis in ruminants: Surgical management and prevention. Compend. Contin. Educ. Pract. Vet., 18: S275-S289.

Van Metre, D.C. and Divers, TJ. 2002. Urolithiasis. In: Smith, B.P. Large Animal Internal Medicine, Mosby, $3^{\text {rd }}$ ed., pp 853-860.

जे.ए.कॉर्बेरा, एम.मोरालेस, एफ.डोरेस्टे, सी.गुटियेर्रेज। बकरियों में प्रयोगात्मक स्ट्रवाइट यूरोलीथिएसिस।

कैनरी उपद्वीप के एक अर्द्ध रेगिस्तानी भाग में जहाँ पर बकरियों में यूरोलीथिएसिस आम है वहाँ पर प्रयोगात्मक स्ट्रुवाइट यूरोलीथिएसिस के अध्ययन हेतु 18-एक वर्षीय मादा कैनेरी बकरियों को 3 समसंख्यक वर्गों में वितरित किया गया। वर्ग अ में 3 भाग मक्का और 1 भाग बिनौले की खली का मिश्रित दाना खिलाया गया; वर्ग ब में अ का दाना इच्छानुसार भूसे के साथ खिलाया गया और वर्ग स में 10 सप्ताह तक संतुलित आहार खिलाया गया। सभी वर्गों में रवेदार मूत्र पाया गया, परन्तु वर्ग अ में अधिक था। इस वर्ग की बकरियों में कैल्शियम-फास्फोरस का असंतुलन बढ़ता गया। वर्ग अ में उपकलीय कोशिकाएं और बिलीरुबिन के रबे भी अधिक थे। निष्कर्ष यह निकला कि बकरियों को अधिक अन्नयुक्त आहार खिलाने पर स्ट्रुवाइट यूरोलीथिएसिस अधिक होती है। 